High-Energy Intermediate or Stable Transition State Analogue: Theoretical Perspective of the Active Site and Mechanism of $\beta$-Phosphoglucomutase

Charles Edwin Webster

Contribution from the Department of Chemistry, Texas A\&M University, College Station, TX 77843-3255

Table S1: H-bonds to the active site:

\begin{tabular}{cccc} 
Location $^{\mathrm{a}}$ & group & residue \# & active site component \\
\hline front top & $\mathrm{OCO}^{-}$ & GLU 169 & $\mathrm{H}_{2} \mathrm{O}(128)$ \\
front top & $\mathrm{RNH}^{+}$ & LYS 145 & $\mathrm{X}_{\mathrm{f}}$ \\
middle right & backbone NH & ALA 115 & $\mathrm{X}_{\mathrm{f}}$ \\
middle right & $\mathrm{ROH}$ & SER 114 & $\mathrm{X}_{\mathrm{r}}$ \\
middle right & $\mathrm{OCO}^{-}$ & ASP 170 & $\mathrm{H}_{2} \mathrm{O}(29)$ \\
back top & backbone NH & LEU 9 & $\mathrm{X}_{\mathrm{r}}$ \\
back middle & backbone NH & ASP 10 & $\mathrm{X}_{\mathrm{r}}$ \\
back bottom & $\mathrm{OCOH}$ & ASP 10 & $\mathrm{O}^{2}$ of phosphoglucose \\
middle center & $\mathrm{COH}$ & $\mathrm{G} 16 \mathrm{O}^{3}$ & $\mathrm{X}_{\mathrm{b}}$ \\
middle bottom & $\mathrm{H}_{2} \mathrm{O}$ & $\mathrm{H}_{2} \mathrm{O}(68)$ & $\mathrm{H}_{2} \mathrm{O}(29)$
\end{tabular}

\title{
Theoretical Calculations
}

The theoretical calculations have been carried out using the Gaussian03 ${ }^{1}$ implementations of B3LYP [Becke three-parameter exchange functional (B3) ${ }^{2}$ and the Lee-Yang-Parr correlation functional (LYP) $\left.{ }^{3}\right]$ density functional theory (DFT), ${ }^{4} \mathrm{PM} 3 \mathrm{MM},{ }^{5}$ and ONIOM(MO:MO). ${ }^{6}$ All calculations used the default pruned fine grids for energies $(75,302)$, default pruned course grids for gradients $(35,110)$, and default SCF convergence for geometry optimizations $\left(10^{-8}\right)$. All B3LYP atoms (103 atoms) were fully optimized, while all outer atoms were treated with PM3MM and were frozen at their crystallographic positions (specific atoms were allowed to relax: the hydrogens of $\mathrm{H}_{2} \mathrm{O}(39)$, the $\mathrm{OH}$ hydrogens of THR16 and SER116, and the entire 6phospho group). The basis set utilized the 6-31G(d) basis sets of Pople and coworkers ${ }^{7 \mathrm{a}}$ for magnesium and phosphorus; all bound oxygen and fluorine, and nitrogen and oxygen involved in hydrogen bonding to active site utilized the $6-31 \mathrm{G}\left(\mathrm{d}^{\prime}\right)$ basis sets ${ }^{7 \mathrm{~b}, 8}$ and all distant carbon, oxygen, and hydrogen utilized STO-3G basis sets. ${ }^{7 \mathrm{c}}$ The $6-31 \mathrm{G}\left(\mathrm{d}^{\prime}\right)$ basis set has the $d$ polarization functions for $\mathrm{C}, \mathrm{N}, \mathrm{O}$, and F taken from the $6-311 \mathrm{G}(\mathrm{d})$ basis set, ${ }^{9}$ instead of the original arbitrarily assigned value of 0.8 used in the $6-31 \mathrm{G}(\mathrm{d})$ basis set. All relative energies are extrapolated ONIOM relative energies.

Second derivatives are numerical for PM3 in Gaussian 03 and are currently prohibitively expensive to calculate for a model this large. Therefore, the frequency analysis confirming one imaginary frequency $\left(147 i \mathrm{~cm}^{-1}\right)$ for the for phosphoryl transfer transition state was performed on the B3LYP portion of the ONIOM optimized geometry with the ONIOM link atoms replaced with frozen hydrogen atoms at a bond length scaled by the specific g-factor parameter ${ }^{6}$ for each specific ONIOM cut. This truncated structure does not represent a true stationary point on the B3LYP potential energy surface, but this calculated Hessian will give the approximate nature of the true stationary point for the entire ONIOM(B3LYP:PM3MM) model.

The figure of the entire model was created with $\mathrm{JIMP}^{10}$ and Povray ${ }^{11}$. The anaglyphs were created with an SDK interface with Cerius ${ }^{2} .{ }^{12}$ The animations of the rotation of the transition state and the imaginary mode of the truncated model were created using Molden 4.0 beta $^{13}$ and Whirlgif $3.04 .^{14}$ 
This figure represents the optimized structure of $\mathrm{MgF}_{3}=\mathrm{YX}_{3}$, the transition state analogue. The model employed in the current study is based on the active site of the PGM enzyme with the 30 surrounding residues (103 B3LYP atoms, 390 total atoms). The total charge of this species is 1-, and the charge of the DFT core is 2-. All backbone atoms of 29 of the 30 neighboring residues were included; for LYS145, only the R group was included. The R groups (distant from the active) of several amino acid residues (PHE7, LEU168, ASP15, ILE13, VAL47, and LEU112) were truncated as hydrogens. The active site, bound phosphoglucose (as noted above, the 6-phospho group was treated with PM3MM and was allowed to optimize), $\mathrm{H}_{2} \mathrm{O}(68)$, and the neighboring residues were freely optimized using DFT, while the outer atoms (in yellow) were constrained in space at their crystallographically determined locations (except certain atoms involved in hydrogen bonds noted above) and PM3MM energy calculations were performed.

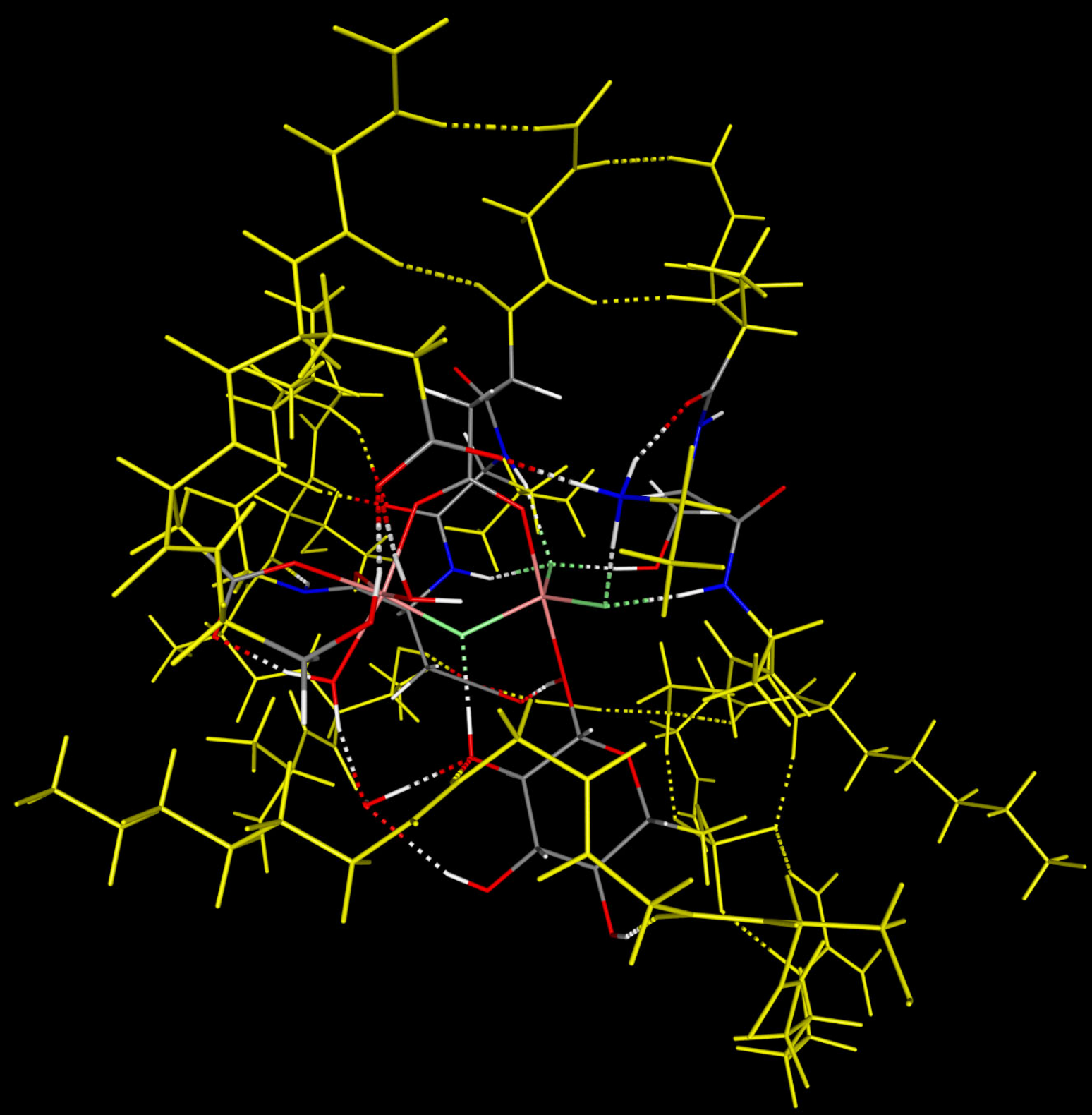


Anaglyph for structure of $\mathrm{MgF}_{3}=\mathrm{YX}_{3}$, the transition state analogue (viewed with left(red)/right(blue) “3-D” glasses)

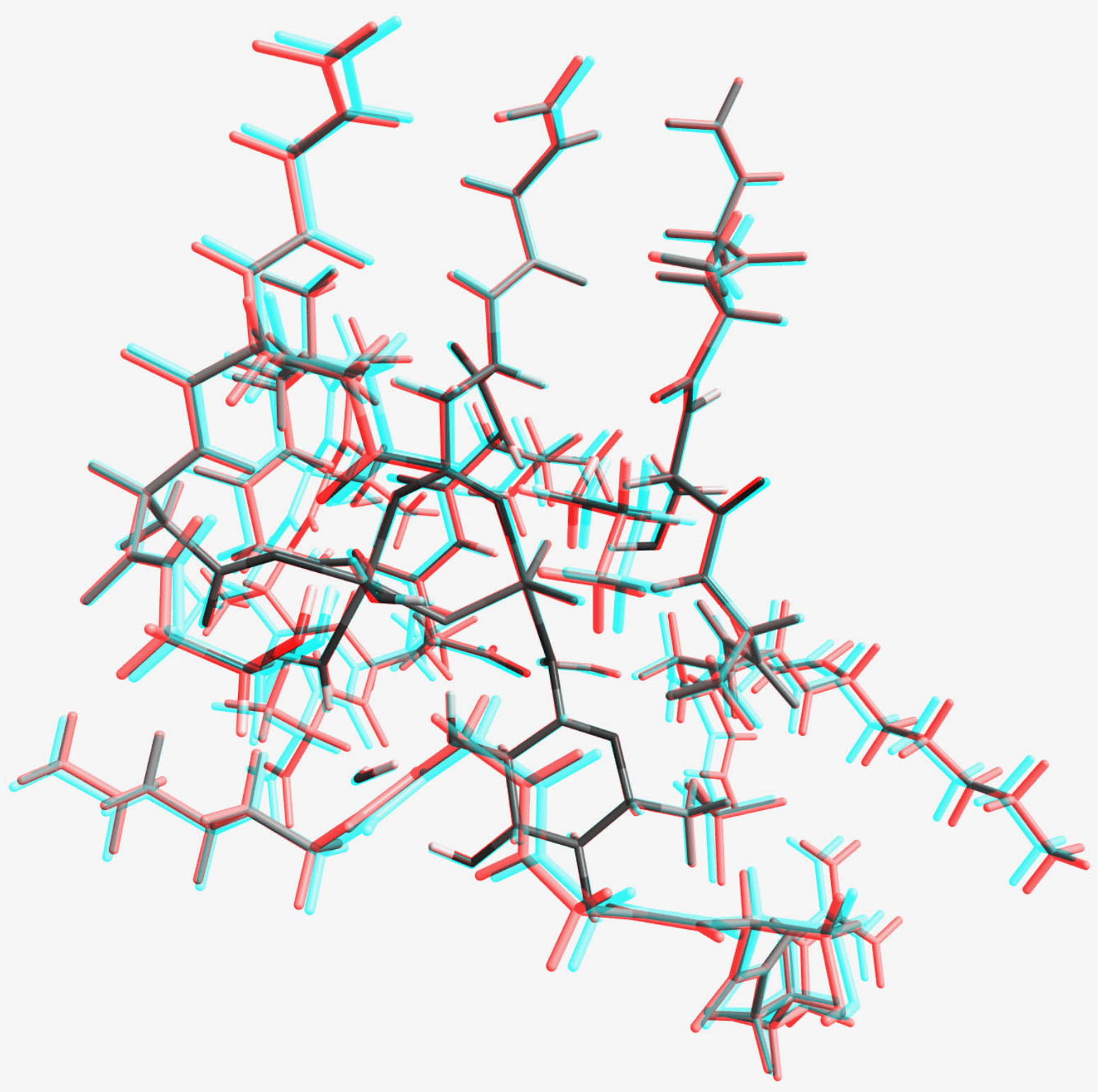


Anaglyph for structure of the $\mathrm{PO}_{3}=\mathrm{YX}_{3}$, the hydrogen bound glucose 6-phosphate species

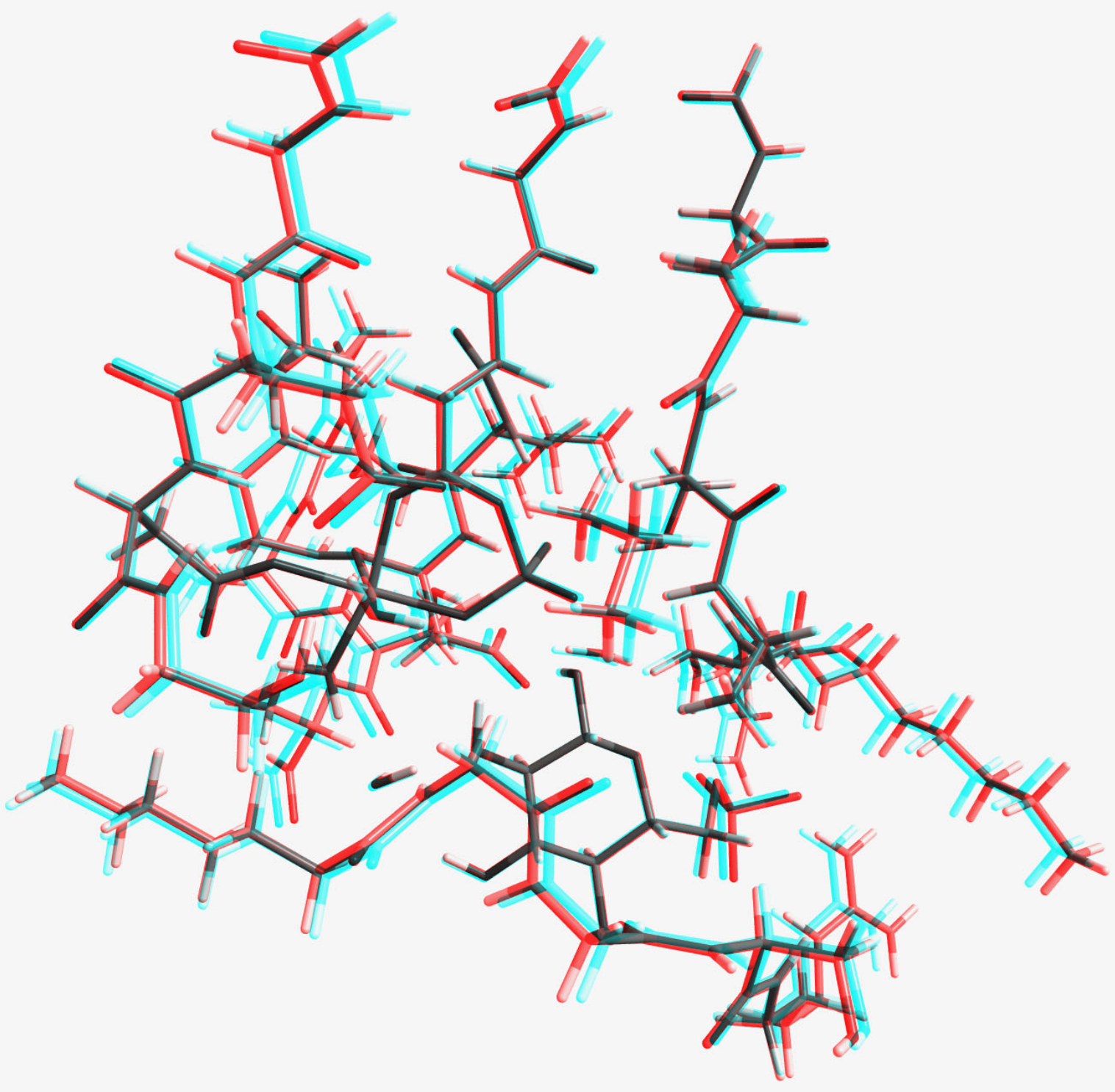


Anaglyph for structure of the $\mathrm{PO}_{3}=\mathrm{YX}_{3}$, the transition state for phosphoryl transfer

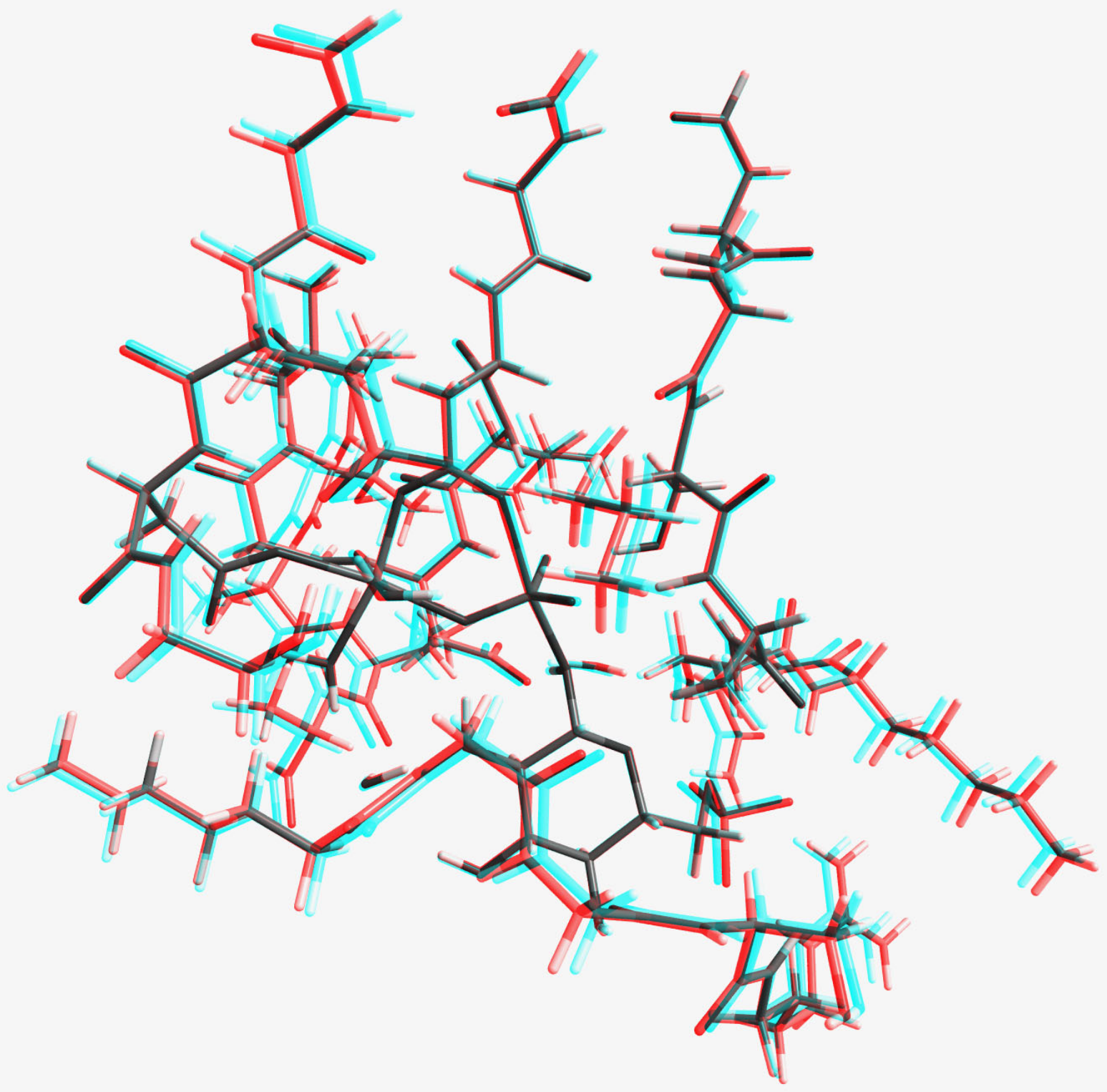


Anaglyph for structure of the $\mathrm{PO}_{3}=\mathrm{YX}_{3}$, the hydrogen bound glucose 1,6-bis-phosphate species

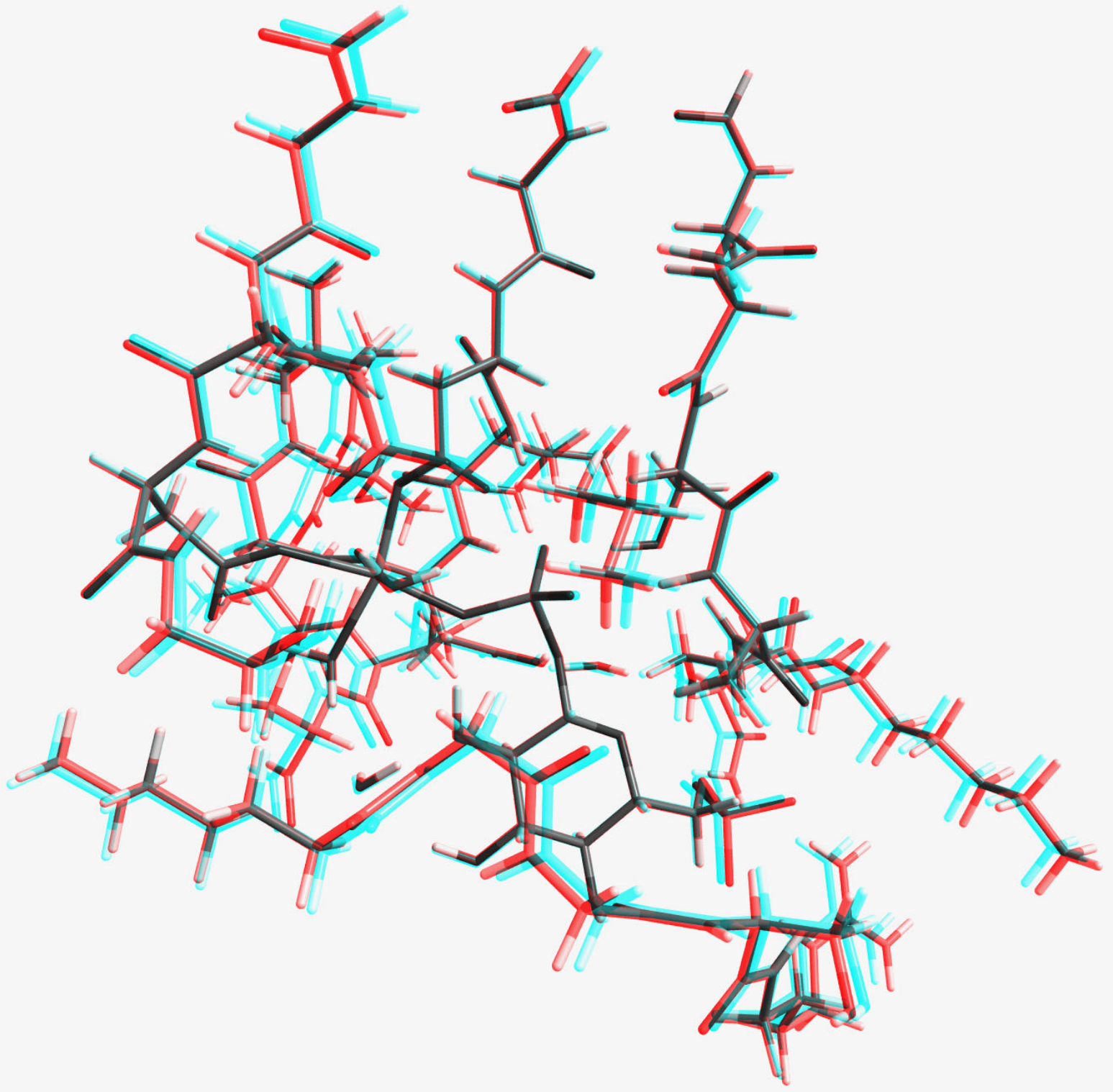


${ }^{1}$ Frisch, M.J.; Trucks, G.W.; Schlegel, H.B.; Scuseria, G.E.; Robb, M.A.; Cheeseman, J.R.; Montgomery, J.A., Jr.; Vreven, T.; Kudin, K.N.; Burant, J.C.; Millam, J.M.; Iyengar, S.S.; Tomasi, J.; Barone, V.; Mennucci, B.; Cossi, M.; Scalmani, G.; Rega, N.; Petersson, G.A.; Nakatsuji, H.; Hada, M.; Ehara, M.; Toyota, K.; Fukuda, R.; Hasegawa, J.; Ishida, M.; Nakajima, T.; Honda, Y.; Kitao, O.; Nakai, H.; Klene, M.; Li, X.; Knox, J.E.; Hratchian, H.P.; Cross, J.P.; Adamo, C.; Jaramillo, J.; Gomperts, R.; Stratmann, R.E.; Yazyev, O.; Austin, A.J.; Cammi, R.; Pomelli, C.; Ochterski, J.W.; Ayala, P.Y.; Morokuma, K.; Voth, G.A.; Salvador, P.; Dannenberg, J.J.; Zakrzewski, V.G.; Dapprich, S.; Daniels, A.D.; Strain, M.C.; Farkas, O.; Malick, D.K.; Rabuck, A.D.; Raghavachari, K.; Foresman, J.B.; Ortiz, J.V.; Cui, Q.; Baboul, A.G.; Clifford, S.; Cioslowski, J.; Stefanov, B.B.; Liu, G.; Liashenko, A.; Piskorz, P.; Komaromi, I.; Martin, R.L.; Fox, D.J.; Keith, T.; Al-Laham, M.A.; Peng, C.Y.; Nanayakkara, A.; Challacombe, M.; Gill, P.M.W.; Johnson, B.; Chen, W.; Wong, M.W.; Gonzalez, C.; Pople, J.A. Gaussian 03, rev B.04; Gaussian, Inc.: Pittsburgh, PA, 2003.

${ }^{2}$ Becke, A. D. J. Chem. Phys. 1993, 98, 5648.

${ }^{3}$ Lee, C.; Yang, W.; Parr, R. G. Phys. Rev. B, 1988, 37, 785.

${ }^{4}$ Parr, R. G.; Yang, W. Density Functional Theory of Atoms and Molecules; Oxford University Press: New York, 1989.

${ }^{5}$ Stewart, J. J. P. J. Comp. Chem. 1989, 10, 209-220; J. Comp. Chem. 1989, 10, 221-264; J. Comp. Chem., 1991, $12,320-341$.

${ }^{6}$ Dapprich, S.; Komáromi, I.; Byun, K. S.; Morokuma, K.; Frisch, M. J. J. Mol. Struct. (Theochem) 1999, 462, 121.

${ }^{7}$ a) Francl, M. M.; Pietro, W. J.; Hehre, W. J.; Binkley, J. S.; Gordon, M. S.; DeFrees; D. J.; Pople, J. A. J. Chem. Phys. 1982, 77, 3654-3665; b) Hariharan, P. C.; Pople, J. A. Theoret. Chimica Acta 1973, 28, 213-222; c) Hehre, W. J.; Stewart, R. F.; Pople, J. A. J. Chem. Phys. 1969, 51, 2657-2664.

${ }^{8}$ Petersson, G. A.; Al-Laham, M. A. J. Chem. Phys. 1991, 94, 6081; Petersson, G. A.; Bennett, A.; Tensfeldt, T. G.; Al-Laham, M. A.; Shirley, W. A.; Mantzaris, J. J. Chem. Phys. 1988, 89, 2193.

${ }^{9}$ Krishnan, R.; Binkley, J.S.; Seeger, R.; Pople, J.A. J. Chem. Phys. 1980, 72, 650; Clark, T.; Chandrasekhar, J.; Schleyer, P.v.R. J. Comp. Chem. 1983, 4, 294.

${ }^{10}$ Manson, J.; Webster, C. E.; Hall, M. B. JIMP Development Version 0.1 (built for Windows PC and Redhat Linux 7.3), Department of Chemistry, Texas A\&M University, College Station, TX 77842 (http://www.chem.tamu.edu/jimp/)

${ }^{11}$ POV-Ray: POV-Team co/ Hallam Oaks P/L, P.O. Box 407, Williamstown, Victoria, 3016 Australia (http://www.povray.org)

${ }^{12}$ An in-house Cerius ${ }^{2}$ SDK that creates anaglyphs with Cerius ${ }^{2}$ written by J. Manson. Cerius ${ }^{2} 4.8$ : Accelrys Inc., 9685 Scranton Road, San Diego, CA 92121-3752, USA; (http://www.accelrys.com/)

${ }^{13}$ Schaftenaar, G.; Noordik, J.H. J. Comput.-Aided Mol. Design, 2000, 14, 123-134; Molden 4.0 beta (http://www.cmbi.kun.nl/ schaft/molden/molden.html)

${ }^{14}$ Whirlgif: Dinsen-Hansen, H.; Kadow, K.; Podlipe, M. Whirlgif Revision 3.04 (http://www.danbbs.dk/ dino/whirlgif/) 